\title{
Advances in Mining Engineering Education: A Case for Learning Communities
}

\author{
http://dx.doi.org/10.3991/ijep.v5i2.4469 \\ M. Hitch \\ University of British Columbia, Vancouver, B.C., Canada
}

\begin{abstract}
Mining engineering involves the design, planning and management of operations for the development, production and eventual rehabilitation of resource extraction. These activities draw on a diverse set of skills. University of British Columbia mining engineers have traditionally been highly regarded for their strengths in the technical aspects of mining and mineral process but also for their understanding of the application of principles of sustainability and social responsibility. The current view of the UBC Mining curriculum demands the integration of aspects of environmental and social sciences shaping the future of tertiary engineering education. The solution is developing a curriculum that is focused on key learning objectives that are a reflection of all these external pressures. This paper examines the challenge of curriculum reform and the emergence of learning communities at the Norman B. Keevil Institute of Mining Engineering at the University of British Columbia, Canada.
\end{abstract}

Index Terms-Engineering Curriculum, Engineering Education, Learning Communities, Mining Engineering.

\section{INTRODUCTION: THE EVOLVING LANDSCAPE OF HIGHER LEVEL TECHNICAL EDUCATION}

In engineering education, there are several challenges that educators face in the development, course delivery and student assessment of their courses. There is distinct pressure on the curricula taught from such quarters as national accreditation boards, Applied Science faculties, Industry advisory boards and student exit surveys.

These driving forces and personal convictions about the importance of engineering education have led to widespread questioning of the viability of the way engineering has historically and is currently taught. The following paper describes the new mining engineering criteria that was approved in June 2010 at the Norman B. Keevil Institute of Mining Engineering at the University of British Columbia in Canada (NBK/UBC). An innovative approach to curriculum reform was incorporated acknowledging the challenges and opportunities that mining engineers will face as they enter the workforce and pursue rewarding careers.

\section{THE UNIVERSITY OF BRITISH COLUMBIA CONTEXT}

An undergraduate mining engineering curriculum reflects the unique circumstances and history of the department granting the degree. Thus, it is important to understand the NBK/UBC context at the outset in order to place the discussion of the ensuing curriculum change in context. The opportunity to completely modify an entire undergraduate curriculum, rather than marginally change a few courses makes the NBK/UBC experience different that most curriculum activities.

The Norman B. Keevil Institute of Mining Engineering has approximately 150 undergraduate students and in 2009-2010 granted 25 bachelors of applied science (B.A.Sc.) degrees. With approximately 106 (2010-2011) graduate students, the department is one of the largest in Canada. The department's nine professors are expected to pursue an active research program as well as teach two undergraduate courses per semester and one graduate course per academic year, on average.

In 2007, the department began a formal strategic planning process that resulted in the periodic examination of the educational direction of the unit. The department's initial plan focused on educational objectives and the steps necessary to accomplish them. Thus when the time came to redesign the undergraduate program, considerable attend had been paid to the professional demands of the future of mining engineering and their relationship to an undergraduate education.

A set of educational objectives and outcomes served as the point of departure for the development of a revised curriculum. These outcomes reflected those characteristics of the degree program that were considered critical by the faculty and which, through a variety of means, were similarly viewed by other important constituencies (e.g. Industry Advisory Committee).

The program outcomes closely reflected the accreditation criteria for Canadian Engineering Accreditation Board $(\mathrm{CEAB})$, in which engineering programs must demonstrate that their graduates have specific abilities and knowledge upon graduation. Although the CEAB criteria were important, a number of other means were used to determine the most appropriate outcomes for the educational program. Students at NBK/UBC use annual surveys to provide their opinion concerning the quality of the course in terms of what is taught and how it is delivered. This differs from the end of term course evaluations that focus directly on the respective professor's success over the term. The student responses reflect their experiences during the three eight month co-op work terms. The survey results often reflect similar issues, as do the Industry Advisory Committee (IAC) workshops.

The department's external IAC also provide insight into the desirable characteristics of both the graduates of the program as well as the curriculum. The program outcomes that result from all of these inputs become an important means of framing the discussion for future curriculum development.

The mining department also benefitted from some faculty members completing the UBC Faculty Certificate in 
the Scholarship of Teaching and Learning. From these efforts, the department was receptive to a new approach to curriculum development and reform through the use of collaborative and integrative model of curricular learning communities.

\section{FOUNDATIONS OF CURRICULUM REFORM THROUGH LEARNING COMMUNITIES}

Curricular learning communities are a purposeful attempt to create rich, challenging and nurturing academic communities where they might not otherwise exist; see [1] and [2]. Proponents of this approach presume that the purposeful creation of academic community is necessary, especially where the decision-making dynamic involves several powerful interest groups. This is a complex, multifaceted challenge that requires rethinking the way the curriculum is divided into discrete three-or four-credit classes, the connection between courses, and the way they are taught.

In their most basic form, curricular learning communities intentionally cluster two or more courses taken by a cohort of students, typically around an interdisciplinary theme. There is a great diversity in the type of structures and models that exist, requiring different levels of faculty and student engagement, faculty collaboration and restructuring of the students' and faculty's time, credits and activities [2]. These systems are particularly effective in the university Environment because, rather than using the traditional lecture format, it forces the students to take a more active and responsible role in the learning process, causing students to look forward to the class, to feel respected and needed in the pursuit of knowledge, and to respect and rely upon each other in these endeavours [3].

The learning community approach fundamentally restructures the curriculum, and the time and space of students. Curricular learning community models intentionally link together courses or coursework to provide greater curricular coherence, more opportunities for active learning, and interaction between students and faculty. Changes in linked courses, for example, may simply combine a skills course and a content course with little change in the pedagogy. Reconfiguring time and space is absolutely essential to create a more effective arena for learning.

Curricular learning communities are usually associated with collaborative learning approaches, an emphasis on writing and critical thinking, interdisciplinary studies, and classroom-based assessment. Students are encouraged to become responsible learners, to work with the complexity of real-world problems, and to develop a personal voice or point of view. While little research has been done to compare the different models, preliminary evidence suggests that the more thematically integrated and team-taught models do have higher pay-off in terms of student engagement and learning (Figure 1).

Similarly, problem-based learning immediately draws upon the same learning skills associated with learning communities. Engineering in particular fosters the notion of 'learning by doing' and students are directly able to link the theoretical knowledge and the practical problem. Curricular learning communities provide the support for a systems approach to design and operational performance and the ability to function effectively as an individual in a multi-disciplinary and multi-cultural team.

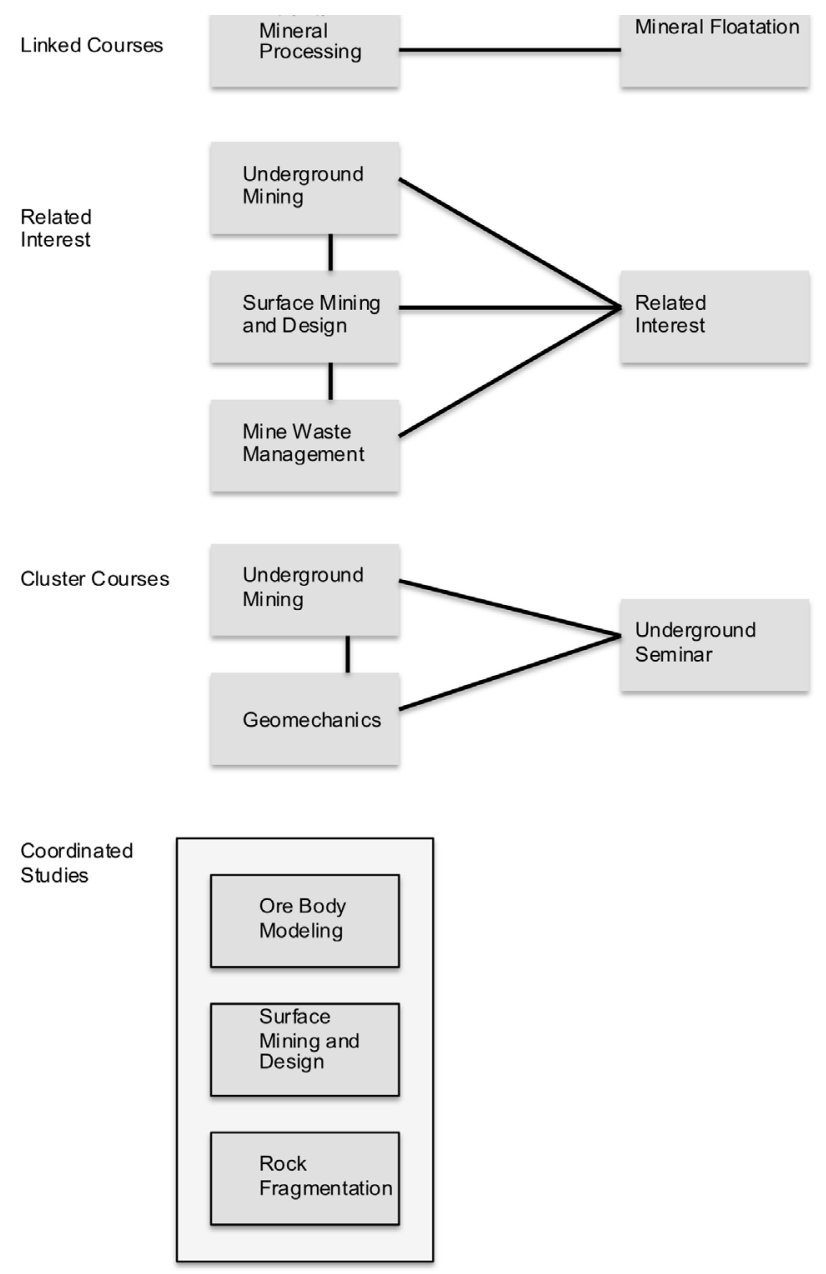

Figure 1. Some common curricular learning community models

Engineering, mining engineering in particular is no longer a single dimension discipline. Most, if not all engineering problems involve aspects of social, cultural and environmental importance, not to mention other engineering discipline inputs. Project-oriented capstone course development depends on the incorporation and synthesis of multiple areas of expertise that serves not only to enrich the outcome of the problem solving exercise but also to encourage students to critically analyze 'real-world' tasks in an educational setting while dealing with the softer issues such as interpersonal communication and teamwork.

The curricular learning community effort is especially important because it can provide a comprehensive context for curriculum reform. The effort firmly recognizes the complexities of higher education today and the powerful forces of fragmentation.

\section{ELEMENTS OF SUCCESS OF LEARNING COMMUNITIES}

The success of curriculum reform through learning communities is dependent on a number of factors both within and outside the sphere of influence of an individual faculty department. Engstrom [4] posits four contributions that create engaging curricular learning environments. These include:

- Active learning pedagogies. Through the use of active learning pedagogies, faculty can create vehicles for students to familiarize themselves with each other 
PAPER

ADVANCES IN MINING ENGINEERING EDUCATION: A CASE FOR LEARNING COMMUNITIES

and develop respect and trust, leading to students' increased comfort in participating in a community of learners.

- Faculty collaboration and an integrative curriculum. Faculty must work together to develop curricular links between courses. Students perceive these integrated experiences to foster deeper learning, student engagement, fluid teacher-learner roles, and more efficient use of their time.

- Development of wider learning strategies. Faculty can introduce structured opportunities and even incentives for students to learn skills, habits and competencies critical to navigating their University program and promoting ongoing academic success.

- Student validation. Faculty will validate students through their high expectations, recognition of students' expertise and knowledge, and their continued assurance that they were able to perform at the highest level.

Each one of the aforementioned elements is almost a teaching/learning strategy unto its own. To achieve each and every one of these, there are several conditional aspects that drive or motivate the development of the curricular learning community.

\section{A. Institutional Self Determination and Autonomy}

According to self-determination theory, psychological needs are nutriments essential for psychological growth and well being in every human being [5] [6]. Specifically, the theory posits that within any significant life domain, opportunities to experience autonomy, competence, and relatedness (each representing a basic psychological need) are essential in promoting life satisfaction and well being. This sense of well being can easily translate to the individual faculty department. Individual members of the department naturally tend toward contexts, activities, and relationships that support the satisfaction of these needs. This suggests that on any given day, satisfaction of each of these basic needs is a necessary condition for wellbeing and effective functioning. This is a critical feature in the early development of curricular learning communities (i.e. to achieve the level of comfort to collaborate and share ideas, content, materials and values).

\section{B. Identity}

An Institutional identity, although variously perceived, has a reality independent of individual members and its significance depends on a collective audience, amongst whom there is a level of internal consensus in the form of a shared vision/mission statement and thematic focus. This is quite different from what some management scientists refer to as organizational identity or the construed external image [7]. Although independent from the constituent members' individual identity, they are closely linked and the development of learning communities is just one other way of articulating the reciprocal nature of these relationships. Institutional identity is best understood as contested and negotiated through iterative interactions between managers and stakeholders and their meaning for strategic action. The stakeholders in the case of NBK/UBC include students, staff, faculty, and the Industrial Advisory Committee. It is the discourse amongst these stakeholders that shapes and colours how we see ourselves in relation to the mandate.

\section{Personalization}

Because individual identity and organizational identity are mutually and reciprocally linked, they are largely conducted for others in order to convey impressions that serve the individuals' self- interests. Educators seek to define and understand phenomena themselves and to impress their understanding on others through an interaction occurring in a particular context with a salient classroom audience. Professors and instructors enter a social interaction with prior beliefs about their self-concepts, values, and goals, and they make initial assessments of classroom audience (e.g. their expectations, goals, and beliefs) and situational characteristics (e.g. social rules and roles) within which interaction will occur. This level of personalization is the essence of the learning community model. It is this richness of experience and knowledge that is transmitted in a communal setting that is the wealth intrinsic in the model.

\section{Support for Teaching}

The literature is rich with scholarly work on the relationship between teaching and research. Some believe research increases teaching effectiveness by increasing awareness and currency (e.g. [8]) whereas others (e.g. [9]) believe that research productivity is unrelated to teaching effectiveness. The relationship between teaching and research can never be satisfactorily demonstrated. Learning however is the vital link between research and teaching. It is a shared process in these two enterprises. Learning acts as a powerful intervening factor in all of the studies attempting to demonstrate a relationship between teaching and research since it is the epistemological process whereby an individual - teacher, researcher, student comes "to know". This is not to say that research is wholly about learning any more than facilitating learning is the whole of teaching. But learning is the significant and substantial element shared by research and facilitated learning. Teaching and research are correlated where they are corelated, (i.e. when what is being related are two aspects of the same activity = learning).

\section{E. Functional Accountability}

Active learning and curricular learning communities are the embodiment of continuous improvement systems. Critical to their success are the multiple forms of assessment beyond the traditional students' grade and resulting teaching assessment at the end of the term. Assessment strategies with curricular learning communities reflect personal learning and the ability of the student to demonstrate knowledge.

Another important aspect is maintaining credibility and under this model, with the students' achievement being the ultimate measure as well as demonstrating credibility. There is a clear emphasis on demonstrating and actually 'being' a faculty with an attitude of efficacy, commitment and collective responsibility for student learning.

\section{BARRIERS TO SUCCESS}

The first barrier to the success of curricular learning communities is cultural expectation. We have a deeply embedded, difficult to displace culture of what university undergraduate education should be and should have. Many of us subscribe to a certain 'collective nostalgia' when it comes to academia. There are certain 'sacred cows' that many people (i.e. likely senior faculty and 
senior administration) are unwilling to consider doing differently.

Another issue that arises is the comprehensive nature of engineering education and the many "moving parts" that comprise a four-year program. Conventionally departmentalized faculty, rigid student placements, standard timetables all combine to make adoption of the curricular learning community model difficult.

Change takes time and certainly a prominent barrier to the success of curriculum reform is the demand by administration for improved results too early in the life of the reformed curriculum. The demand for instant evidence of success often leads to compromises that seem necessary for survival but decrease the possibility for long-term success [10].

Carefully developed standards adequately serve university departments, faculties and the profession as a whole. Unfortunately, the approved criteria restrict the adoption of more new material given the time constraints of a four year program. To a large extent, this approach has made almost impossible the fast, entrepreneurial, highflexibility, customer-driven response that is admired in the world of engineering practice.

Some faculty, many of who have been teaching for a long time, perceives the critique and close examination of what and how they teach to be personal and respond defensively. It is important to bring these department members on side and demonstrate how collaborative teaching models and the community based model are a benefit to them in terms of both time and energy required.

There may be a tendency to get 'caught between the why and how' of curriculum reform. It is important for early, broad-based involvement by all stakeholders in decisions and detailed planning. Workshops, surveys and hallway discussions bring focus to the benefits of the proposed reform.

Finally, there is a human temptation to settle for too little. We may believe that external forces prevent us from having more than complete success. We need to test the boundaries of those things we believe limit our options.

We now move on to a discussion of how curricular learning communities were applied to a mining engineering department at the University of British Columbia; Canada's second largest comprehensive university.

\section{CURRICULUM REFORM AT NBK INCORPORATING LEARNING COMMUNITIES}

So far in this paper we have introduced the NBK/UBC context and the whys and wherefores of curriculum learning communities. As indicated above, there are new mandates and requirements to implement explicit learning outcomes and assessment policies for all undergraduate curricula. The literature is rich with cases of faculties' responses to all of the mentioned external pressures that are common to the experience at the University of British Columbia [11].

When the mining engineering department (NBK/UBC) was faced with a need to revisit its curriculum, a staged approach to its development and implementation was employed. For clarity, these stages or integration phases are presented using the terminology presented by [12] and include:
- From Pre-awareness Stage to Awareness Stage. At this stage all stakeholders are made aware of the external motivations for curriculum reform (e.g. meetings, workshops, surveys, seminars),

- From Awareness Stage to Initiative Stage. At this stage the curriculum reform team is selected,

- From Initiative Stage to Mobilization Stage. At this stage there is a mobilization of a critical mass of faculty members to begin considering what curriculum means to them and consider where efficiencies exist,

- From Mobilization Stage to Action Plan Stage. At this stage there should be an overall shared vision and model of curriculum with specific attention to learning outcomes and vertical and horizontal curriculum integration, and

- From Action Plan Stage to Practice Stage. Curriculum changes need to be approved at the faculty level executed and continually monitored for their success.

The progress of the curriculum reform, measured using these stage descriptions, are presented below. It should be noted that in the case of the NBK/UBC, some of these stages were either blended or not as fully developed as [12] propose.

\section{A. From Pre-awareness Stage to Awareness Stage}

At the end of the winter term in 2007, the students conducted a survey to poll opinion as to the relevance of a number of courses in the existing curriculum. The survey polled the relevancy of course work to their industry experience. Furthermore the survey provided the opportunity for the students to provide feedback on every course taken during their academic career in the department.

The Industry Advisory Committee was then polled and a facilitated meeting was held to provide feedback from industry's perspective of what a mining engineering curriculum should contain, particularly the newly hired engineer entering the workforce for the first time.

The mining engineering department had been under a reduced three-year accreditation period (i.e. largely due to space restrictions) and was aware of a pending CAEB review. The faculty was very aware of the evolving requirements for accreditation and was beginning the planning cycle to achieve them.

Finally, each faculty member was asked to reflect on what they taught and ways in which the methods and materials could be updated to meet the changing needs that had been identified.

Based on these motivators, it was concluded that some measure of curriculum reform was required. For the most part, there was consensus amongst all faculty members and an emerging sense of cooperation was developing.

Additionally, there was a need to review and adsorb the NBK 5 Year Strategic Plan as defined by the NBK department, and frame any potential curriculum changes to closely align with the department's mission statement and educational statement of purpose. It was concluded that three areas that needed attention and could be addressed with some measure of curriculum reform included:

1. A skillset/toolkit to prepare the graduating student for a changing world. This included an emphasis on critical thinking and continuous self learning; 
2. An integrated approach to curriculum and course development including aspects of mine-mill integration and an overall switch to more complex systems thinking; and

3. Establishing a learning continuum that consists of recurring themes or threads that move through one course to others.

Based on these conclusions, an offsite curriculum workshop was planned.

\section{B. From Awareness Stage to Initiative Stage}

The purpose of the retreat was to look at our curriculum and to assess any needs for future change in light of the inputs received. This involved the analysis of what may work, what doesn't work and how it can be fixed. An important aspect was the recognition that there needed to be serious action and implementation beyond just planning. The then current undergraduate advisor, curriculum committee, and the incumbent curriculum advisor were assigned the task to lead the group through a facilitated development exercise and to address the issues raised in the undergraduate survey, IAC workshop, accreditation expectations, faculty expectations of knowledge gaps and areas of needed focus, and alignment with the department's areas of teaching focus. At the onset of the retreat we discussed whether the curriculum required a radical overhaul or just incremental changes to make it more reflective of the collective vision. The results of the sessions at first glance appear incremental, however, the overall result was more radical in total.

\section{From Initiative Stage to Mobilization Stage through to Action Stage}

Based on the feedback from the students and the IAC, there was a long discussion about how the curriculum should change. Proposed changes included:

1. Combining a mineralogy and petrology course taught by an outside department and faculty (e.g. Department of Earth and Ocean Sciences, Faculty of Science), with an internal course on process mineralogy. It was felt that the material could be streamlined to suit mineral processors specifically as opposed to a general mineralogy course open to all faculties (Related Interest model of Figure 1). Furthermore, it was determined that more chemistry needed to be included in this course.

2. The second year statistics course is taught by the Department of Statistics and is designed as a universal statistics course for all engineering students. The Statistics Department also offers the same course under a different number to science faculty students. The message from the students was that the material taught had little to do with statistical applications in mining and all of the examples used in the course were foreign. Furthermore, the department faculty found that in the $3 \mathrm{rd}$ and 4 th year courses where statistics played a greater role in problem solving and analysis, the students retained little. For reasons beyond the scope of this paper, it was decided to work with the Statistics Department to provide problem sets that were relevant to the mining course of study.

3. Due to the increasing demand of the CEAB and the faculty's belief that more material was needed, the introductory course of mining and mineral processing was split into two separate courses, each of three credits. These courses would be taught in terms one and two of the second year (Reverse Related Interest model of Figure 1).

4. The IAC indicated that graduating students required more leadership and project management skills for the workplace. It was concluded that each of the third and fourth year design courses be amended to emphasize these traits and incorporate more team and project oriented assignments.

5. It was concluded that we should blur the distinction between mining and mineral processing. Processing starts at the pit wall or at the face but the overall goal is to produce metal or minerals. Much of the department's research involves mine-mill integration and therefore we should emphasize this model. This is similar to the Coordinated Studies model (Figure 1). This may ultimately enable the department to eliminate the current practice of two constrained elective streams; one for mining engineering and one for mineral processing. Most graduating students take both streams as a general practice and this would allow credit room for four new elective courses.

6. All survey sources and opinions of the faculty concluded that there had to be more linkages between individual courses (Linked Courses model from Figure 1.) These efforts will be part of a continual improvement model encouraged by the CEAB.

7. Technical courses (e.g. Surface Mining and Design and Underground Mining) should be taught in the same year (Year 3) in order to give the student the fundamental building blocks needed to complete their 4th year senior design projects. For the same reason, the second year Ore Body Modeling course was moved to 3 rd year.

8. Several courses were brought in-house (i.e. not taught by outside departments and faculties) to more accurately address problems specific to mining and mineral processing. Other courses were strengthened to include increasingly relevant new material.

Examples of changes to the NBK/UBC Curriculum are presented in Figure 2.

\section{CONCLUSION}

The development of the mining engineering curriculum described in this paper was based on several principles that are likely to serve as basic points for departure for similar curriculum development activities.

Learning communities do not represent the final answer to student learning. As with any other pedagogy, there are limits to their effectiveness. Some students do not like learning with others and some faculty find collaborating with other faculty and staff difficult. Nevertheless, like other efforts to enhance student involvement in learning, such as cooperative learning and service learning, there is ample evidence to support the contention that their application enhances student learning and persistence and enriches faculty professional lives. It is no surprise, then, that so many institutions have initiated learning communities and a number of foundations have established programs to support their development.

But curriculum redevelopment and learning communities are ultimately limited insofar as they can only respond 
PAPER

ADVANCES IN MINING ENGINEERING EDUCATION: A CASE FOR LEARNING COMMUNITIES

\begin{tabular}{|c|l|c|}
\hline \multicolumn{3}{|c|}{ FIRST YEAR } \\
\hline COURSE & \multicolumn{1}{|c|}{ COURSE NAME } & CREDITS \\
\hline APSC 122 & Introduction to Engineering & 0 \\
\hline APSC 150 & Engineering Case Studies & 6 \\
\hline APSC 160 & Computation in Engr Design & 3 \\
\hline CHEM 154 & Chemistry for Engineering & 3 \\
\hline ENGL 112 & $\begin{array}{l}\text { Strategies for University } \\
\text { Writing }\end{array}$ & 3 \\
\hline MATH 100 & $\begin{array}{l}\text { Differential Calculus } \\
\text { Application }\end{array}$ & 3 \\
\hline MATH 101 & Integral Calculus Application & 3 \\
\hline MATH 152 & Linear Systems & 3 \\
\hline PHYS 153 & Elements of Physics & 6 \\
\hline PHYS 170 & Mechanics 1 & 3 \\
\hline & $\begin{array}{l}\text { Complementary Studies } \\
\text { Electives }\end{array}$ & 3 \\
\hline & Sub-Total & 36 \\
\hline
\end{tabular}

\begin{tabular}{|c|l|cc|}
\hline \multicolumn{4}{|c|}{ SECOND YEAR } \\
\hline COURSE & \multicolumn{1}{|c|}{ COURSE NAME } & CREDITS \\
\hline APSC 201 & Technical Communications & 3 \\
\hline CIVL 210 & Soil Mechanics & 4 & \\
\hline EOSC 210 & Earth Sciences for Engineers & 3 & \\
\hline MINE 324 & Applied Mineralogy and & 4 & $\begin{array}{l}\text { Combine } \\
\text { EOS324 } \\
\text { and } \\
\text { PINE338 }\end{array}$ \\
\hline MATH 253 & Multivariable Calculus & 3 & \\
\hline MATH 255 & Differential Equations 1 & 3 & \\
\hline MECH 260 & Mechanics of Materials & 3 & \\
\hline MECH 280 & Fluid Mechanics & 3 & \\
\hline MINE 251 & Mine Statistics (or & 3 & $\begin{array}{l}\text { Develop } \\
\text { from } \\
\text { ETAT251 }\end{array}$ \\
\hline MINE 290 & Introduction to Mining & 3 & \\
\hline MINE 291 & Introduction to Processing & 3 & $\begin{array}{l}\text { Split from } \\
\text { MINE290 }\end{array}$ \\
\hline MINE 293 & Mining Seminar & 1 & \\
\hline & $\begin{array}{l}\text { Complementary Studies } \\
\text { Electives }\end{array}$ & 3 & \\
\hline & Sub-Total & 39 & \\
\hline
\end{tabular}

\begin{tabular}{|c|l|cc|}
\multicolumn{5}{|c|}{ THIRD YEAR } \\
\hline COURSE & \multicolumn{1}{|c|}{ COURSE NAME } & CREDITS \\
\hline APSC 278 & Engineering Materials & 3 \\
\hline APSC 279 & Engineering Materials Lab & 1 & \\
\hline EECE 263 & Basic Circuit Analysis & 3 & \\
\hline MINE 302 & Underground Mining Design & 3 & \\
\hline MINE 304 & Rock Fragmentation & 3 & $\begin{array}{l}\text { Formerly } \\
\text { Drill \& } \\
\text { Blasting }\end{array}$ \\
\hline MINE 305 & Geomechanic Fundamentals & 4 & \\
\hline MINE 310 & Surface Mining and Design & 3 & $\begin{array}{l}\text { Moved } \\
\text { from 4 } \\
\text { year }\end{array}$ \\
\hline MINE 331 & Unit Operations & 3 & \\
\hline MINE 333 & Flotation & 3 & \\
\hline MINE 393 & Mining Seminar & 3 & $\begin{array}{l}\text { Develop } \\
\text { from } \\
\text { MINE295 }\end{array}$ \\
\hline MINE 395 & Ore Deposit Models & 3 & \\
\hline MINE 396 & Mine Economics & 6 & \\
\hline & Technical Electives & 39 & \\
\hline & Sub-Total & \multicolumn{3}{|c|}{} \\
\hline
\end{tabular}

\begin{tabular}{l|l|cc|}
\hline \multicolumn{4}{|c|}{ FOURTH YEAR } \\
\hline COURSE & \multicolumn{1}{|c|}{ COURSE NAME } & CREDITS \\
\hline APSC 450 & $\begin{array}{l}\text { Professional Engineering } \\
\text { Practice }\end{array}$ & 2 & \\
\hline MINE 365 & $\begin{array}{l}\text { Mine Power and } \\
\text { Infrastructure }\end{array}$ & 3 & $\begin{array}{c}\text { Replace } \\
\text { EECE } \\
365\end{array}$ \\
\hline MINE 402 & $\begin{array}{l}\text { Mine Ventilation, Health and } \\
\text { Safety }\end{array}$ & 3 & $\begin{array}{c}\text { Increase } \\
\text { H\&S }\end{array}$ \\
\hline MINE 404 & Mine Life Cycle Systems & 3 & $\begin{array}{c}\text { Formerly } \\
\text { Mine } \\
\text { Manage. }\end{array}$ \\
\hline MINE 432 & Industrial Automation and & 3 & $\begin{array}{c}\text { Revamp } \\
\text { IA \& } \\
\text { Robotics }\end{array}$ \\
\hline MINE 480 & Mine Waste Management & 3 & $\begin{array}{c}1 \text { credit } \\
\text { added }\end{array}$ \\
\hline MINE 491 & Mine and Plant Feasibility & 4 & \\
\hline MINE 493 & Mining Seminar & 1 & \\
\hline MINE 491 & Mining and Environment & 3 & $\begin{array}{c}\text { Move to } \\
4^{\text {th }} \text { Year }\end{array}$ \\
\hline & $\begin{array}{l}\text { Constrained Technical } \\
\text { Electives }\end{array}$ & 6 \\
\hline & Technical Electives & 3 \\
\hline & $\begin{array}{l}\text { Complementary Studies } \\
\text { Elective }\end{array}$ & 3 \\
\hline & Sub-Total & 37 \\
\hline
\end{tabular}

Figure 2. NBK Mining Curriculum (Shadowing indicates curriculum changes)

to the needs of students whose learning experience has been defined and perhaps stunted by the institutions from which they graduated. Part 2 of this argument describes the responsibility and opportunity that the university engineering community has to influence the academic performance of its feeder systems.

\section{REFERENCES}

[1] Gabelnick, F., R. Matthews, J. MacGregor, and B.L. Smith., Learning communities: Creating connections among students, faculty and disciplines. San Francisco: Jossey-Bass, 1990.

[2] Smith, B., J. MacGregor, R. Mathews, and F. Gabelnick, Learning Communities: Reforming Undergraduate Education. San Francisco: Jossey-Bass, 2004.

[3] Minkler, J.E., "ERIC review: Learning communities at the community college." Community College Review, 30 (3), 46-63. 2002. http://dx.doi.org/10.1177/009155210203000304

[4] Engstrom, C. M., "Curricular Learning Communities: How Faculty Can Provide a Foundation for Success." New Directions in Teaching and Learning, 115: 5-19. 2008 . http://dx.doi.org/10.1002/t1.322

[5] Deci, E.L., and R.M. Ryan, "The "what" and "why" of goal pursuits: Human needs and the self-determination of behavior." Psy$\begin{array}{llll}\text { chological Inquiry, } & 11, & 319-338 . & 2000 .\end{array}$ http://dx.doi.org/10.1207/S15327965PLI1104 01

[6] Ryan, R.M., and E.L. Deci, "Self-determination theory and the facilitation of intrinsic motivation, social development, and wellbeing." American Psychologist, 55, 68-78. 2000. http://dx.doi.org/10.1037/0003-066X.55.1.68
[7] Dutton, J.E., J.M. Dukerich, and C.V. Harquail, "Organizational images and member identification." Administrative Science Quarterly, 39: 239-263. 1994. http://dx.doi.org/10.2307/2393235

[8] Centra, J.A., "Research productivity and teaching effectiveness." Research in Higher Education. 18, 4, 379-389. 1983. http://dx.doi.org/10.1007/BF00974804

[9] Webster, David S. "Does research productivity enhance teaching?" Educational Record. 1985.

[10] Wasley, P.A., and R.J. Lear, "Small Schools, Real Gains." Educational Leadership, 58, 6. 2001.

[11] Hubball, H. T., and H.D. Burt, "An Integrated Approach to Developing and Implementing Learning-Centred Curricula." International Journal for Academic Development, 9(1), 51-65. 2004. http://dx.doi.org/10.1080/1360144042000296053

[12] Hubball, H.T., N. Gold, J. Mighty, and J. Britnell, "Supporting the Implementation of Externally Generated Learning Outcomes and Learning-Centered Curriculum Development: An Integrated Framework." New Directions in Teaching and Learning, 115: 93105. 2008.

\section{AUTHOR}

Michael Hitch is with the Norman B. Keevil Institute of Mining Engineering, University of British Columbia, Vancouver, British Columbia, Canada, V6T 1Z4 (email: mhitch@mining.ubc.ca).

Submitted 13 February 2015. Published as resubmitted by the author 07 May 2015. 